811.163.41'367.625

https://doi.org/10.18485/sj.2019.24.1.32

МИЛЕНА Д. ПОПОВИТ ПИЗАРИ*

Универзитет у Београду

Филолошки факултет
Оригинални научни рад Примљен: 11. 09. 2018. Прихваћен: 15. 01. 2019.

\title{
ГЛАГОЛИ КРЕТАҢА И ПРОМЕНЕ ПОЗИЦИЈЕ У ПРОСТОРУ КАО ГЛАГОЛИ СУБЈЕКАТСКЕ КОНТРОЛЕ
}

У раду анализирамо конструкције које се састоје од непрелазних глагола кретања и промене позиције у простору и инфинитива односно њему еквивалентне финитне конструкције $\partial a+$ презент у функцији допуне односно одредбе поменутих глагола. Скрећемо пажњу и на чињеницу да се у разговорном стилу императив непрелазних глагола кретања и промене места у простору, осим с инфинитивом односно његовим финитним еквивалентом $\partial a+$ презент, веома често комбинује и с императивом другог глагола (Иди спавати/Иди да спаваш/Иди cnaвaj). У раду дајемо и преглед различитих типова конструкција $\partial a+$ презент (и с кореферентним и с некореферентним субјектом) употребљених у функцији допуне односно одредбе управних глагола кретања и промене позиције у простору, при чему наводимо и тип успостављене релације контроле (облигаторна, опциона или заједничка).

Кључне речи: глаголи кретања, субјекатска контрола, инфинитив, конструкција $\partial a+$ презент, императив.

\section{1. УВОД}

Осим у виду прилошке, именичке или предлошке синтагме (тј. предлошко-падежне конструкције), непрелазни глаголи кретања и промене позиције у простору у српском језику могу добити допуну односно одредбу

*uudinama@yahoo.com 
и у форми инфинитива односно њему еквивалентне финитне конструкције $\partial a+$ презент, при чему се успоставља релација контроле између граматичког субјекта управне и неисказаног (имплицитног) субјекта зависне структуре. Међутим, и инфинитив и његов финитни еквивалент у функцији допуне односно одредбе непрелазних глагола кретања и промене места у простору подразумевају кореферентност субјеката зависне и управне структуре, те нису једине клаузалне форме у којима се допуне односно одредбе за циљ кретања уз поменуте глаголе могу јавити. Намера нам је зато да у овом раду дамо преглед свих допунских односно одредбених финалних конструкција које се комбинују с непрелазним глаголима кретања и промене позиције у простору, као и да опишемо њихову употребу.

У оквиру литературе о глаголима контроле у српском језику, највише информација нуде Московљевић Поповић (2008) и Московљевић Поповић (2015), у којима ауторка презентује теорију контроле на примеру српских глагола упућујући на релевантну литературу на енглеском језику, а потом на основу прецизних синтаксичких критеријума успоставља врло детаљну класификацију српских глагола контроле наводећи спискове чланова сваке издвојене глаголске поткласе, укључујући и непрелазне глаголе кретања и промене позиције у простору.

Пишући на енглеском језику, српским глаголима контроле односно њиховим инфинитивним и финитним допунама бавили су се и Зец (1987), Проговац (1993; 2005), Белић (2005), Мишкељин (2012), Тодоровић (2012) и др.

\section{2. ГЛАГОЛИ КОНТРОЛЕ}

Глаголима контроле сматрамо све оне глаголе од којих зависе инфинитивне $^{1}$ или финитне ${ }^{2}$ конструкције чији је неисказани (имплицитни) субјекат кореферентан са субјектом (граматичким или логичким) односно објектом (директним или индиректним³) управног глагола. Међу глаголима контроле

${ }^{1}$ Инфинитив без предлога у српском се језику по правилу употребљава у функцији допуне управног глагола. У наставку рада видећемо да инфинитив који зависи од глагола кретања и промене позиције у простору може имати и допунску и одредбену функцију.

${ }^{2}$ У српском језику релација контроле могућа је и у зависним финитним конструкцијама које су комутабилне с инфинитивом и у зависним финитним конструкцијама које нису комутабилне с инфинитивом. С тим у вези, важно је сетити се и чињенице да је инфинитив по правилу комутабилан с финитном конструкцијом $\partial a+$ немобилни презент, док конструкција $\partial a+$ немобилни презент није увек комутабилна с инфинитивом. За више информација о глаголима контроле, њиховим инфинитивним и финитним допунама, као и за примере њихове употребе в. Московљевић Поповић (2008: 95-105) и Поповић Пизари (2018: 6-12; 54-72; 85-89; 123-128).

${ }^{3}$ Термине директни објекат и индиректни објекат употребљавамо као синониме термина прави објекат и неправи објекат. 
разликујемо стога глаголе субјекатске контроле и глаголе објекатске контроле. Глаголи субјекатске контроле јесу сви они глаголи чији субјекат (граматички или логички) „контролише” фонетски нереализовани субјекат инфинитивне или финитне зависне конструкције, док међу глаголе објекатске контроле спадају глаголи чији објекат (директни или индиректни) „контролише” фонетски нереализовани субјекат инфинитивне или финитне зависне конструкције. У примеру ${ }^{4}$ 1а) успостављена је кореферентност између неисказаног субјекта зависне и граматичког субјекта управне структуре, због чега глагол желети сматрамо глаголом субјекатске контроле, док су у примеру 1б) кореферентни неисказани субјекат зависне конструкције и директни објекат управног глагола, те глагол терати сврставамо међу глаголе објекатске контроле.

(1)

a) Желим ти показати нешто/Желим да ти покажем нешто.

б) Терају ме чистити собу/Терају ме да чистим собу.

Важно је нагласити да се између одређеног аргумента управног глагола и неисказаног субјекта зависне конструкције не успоставља увек релација облигаторне контроле. Субјекат односно објекат глагола контроле чија се допуна или одредба реализује у облику инфинитива по правилу облигаторно контролише неексплицирани субјекат инфинитивне конструкције (Мара намерава кренути на пилатес). Међутим, извесни глаголи контроле допуштају могућност арбитрарне интерпретације субјекта зависне финитне конструкције, због чега их можемо сврстати међу глаголе опционе (арбитрарне) контроле (уп. Мара се труди да положи све испите и Мара се труди да (Ана) положи све испите). Постоје и глаголи контроле који допуштају могућност заједничке (подељене) контроле. Овај тип контроле најчешће подразумева да и субјекат и објекат управног глагола истовремено контролишу неисказани субјекат зависне финитне конструкције (Предложила јој је да заједно оду на село).

Постоје два основна типа субјекатске контроле. Први тип се заснива на кореферентности између неисказаног субјекта зависне и граматичког субјекта управне структуре. Зависна конструкција се у овом случају реализује у виду инфинитива или његовог финитног еквивалента $\partial a+$ презент 5 . У наставку наводимо примере употребе трију подврста српских глагола субјекатске кон-

\footnotetext{
${ }^{4}$ Примере које наводимо саставили смо за потребе овога рада по угледу на примере употребе глагола контроле с инфинитивном допуном (односно њеним финитним еквивалентом) на које смо наишли у србистичкој литератури или смо их регистровали у писаном језику новина и других гласила, писаном и говорном језику телевизије, као и у свом и говору својих саговорника. Њихова граматичност потврђена је од стране изворних говорника.

${ }^{5} \mathrm{y}$ вези с инфинитивом и његовим финитним еквивалентом $\partial a+$ презент, желимо да нагласимо да се у овом раду нећемо бавити различитом учесталошћу њихове употребе у односу на територијално, социјално и функционално раслојавање језика.
} 
троле с граматичким субјектом (модални у ужем смислу, модални у ширем смислу ${ }^{6}$ и непрелазни глаголи кретања):

(2)

a) Хтела сам ти објаснити шта се у ствари догодило/Хтела сам да ти објасним шта се у ствари догодило.

б) Намеравамо отићи далеко/Намеравамо да одемо далеко.

в) Иду купити метлу/Иду да купе метлу.

У основи другог типа субјекатске контроле лежи пак кореферентност између неисказаног субјекта зависне и логичког субјекта надређене конструкције. И у овом случају, зависна конструкција се јавља у виду инфинитива или његовог финитног еквивалента $\partial a+$ презент. У наставку су наведени примери употребе српских глагола субјекатске контроле с логичким субјектом:

(3)

a) Допада јој се путовати у друштву/Допада јој се да путује у друштву.

б) Забавља га решавати загонетке/Забавља га да решава загонетке.

\section{3. ГЛАГОЛИ КРЕТАҢА И ПРОМЕНЕ ПОЗИЦИЈЕ У ПРОСТОРУ КАО ГЛАГОЛИ СУБЈЕКАТСКЕ КОНТРОЛЕ}

Као што је у претходном одељку већ назначено (в. 2в)), међу српске глаголе субјекатске контроле спадају и непрелазни глаголи кретања и промене места у простору ${ }^{7}$ (ићи, отићи/одлазити, доћи/долазити, поћи/полазити, прићи/прилазити, кренути/кретати, ући/улазити, изаћи/излазити, стићи/ стизати, сићи/силазити, (по)пети се, трчати/дотрчати/потрчати/отрчати/истрчати/притрчати, тркнути, скокнути, (од)јурити, (од)летети, (по)журити, сести/седати, лећи/легати, бити (= ићи), остатия/остајати,

${ }^{6}$ Терминолошку дистинкцију (семантичке природе) модални глаголи у ужем смислу/модални глаголи у ширем смислу преузимамо из Прањковић (2013: 187-188).

${ }^{7} \mathrm{У}$ српском језику постоје и глаголи кретања и промене позиције у простору који спадају међу глаголе објекатске контроле. У питању су прелазни глаголи попут (по)слати, (од)водити/ одвести/повести, (од)вући/одвлачити, (о)ставити/(о)стављати итд. За више информација о глаголима овог типа в. Мелвингер (1986: 127-128), Московљевић Поповић (2008: 104-105) и Поповић Пизари (2018: 88-89).

8 За више информација о глаголу бити као глаголу промене места у простору в. Мелвингер (1986: 125) и онде наведену литературу.

${ }^{9}$ Мелвингер (1986: 125-126) дефинише глагол остати као глагол којим се означава изостанак промене места у простору. Ауторка, међутим, говори и о инфинитиву у функцији допуне глагола остати који „није конкурентан финалној зависној клаузи него обавезној приложној ознаци за пратећу околност која се може изразити у виду прилога садашњег, најчешће од глагола који означују положај тијела (Грашо је остао стајати)”. 
зауставити се/заустављати се, (за)стати/застајати итд.). Њихову употребу илуструју следећи примери:

(4)

a) Отишли смо набрати малина/Отишли смо да наберемо малина.

б) Пошли смо скупљати пластични отпад/Пошли смо да скупљамо пластични отпад.

в) Били смо купити улазнице за концерт/Били смо да купимо улазнице за концерт.

г) Иду у фабрику вређати раднике/Иду у фабрику да вређају раднике.

д) Иду тамо вређати раднике/Иду тамо да вређају раднике.

У свим наведеним примерима употребе непрелазних глагола кретања и промене позиције у простору постоји кореферентност између неисказаног субјекта инфинитивне конструкције односно њеног финитног еквивалента $\partial a$ + презент и граматичког субјекта управне структуре.

Ако применимо критеријум изложен у Мелвингер (1986: 128), зависна конструкција вређати раднике/да вређају раднике у примерима 4г) и 4д) не би била допунска, већ одредбена (додатна) финална клауза јер је уз управни глагол $u \hbar и$ већ употребљена предлошка ( $у$ фабрику) односно прилошка синтагма (тамо) у функцији допуне за циљ кретања. Уколико пак уз управни глагол кретања нема ни експлицитне ни имплицитне допуне са значењем циља кретања, у том случају финална конструкција у виду инфинитива или његовог финитног еквивалента има статус допуне надређеног глагола (4a), 4б) и 4в)).

Допунска финална клауза у виду инфинитива или његовог финитног еквивалента $\partial a+$ презент одговор је, дакле, на питање које садржи упитни месни заменички прилог са значењем циља кретања Где? (= Камо?)/Куда? (= Камо?), док одредбена финална клауза исте форме представља одговор на питање Зашто?/С којом намером?/Ради чега? и може бити замењена конструкцијом $\partial а+$ потенцијал (Иду у фабрику да би вређали раднике/Иду тамо да би вређали раднике).

Битно је нагласити и да употреба инфинитива (али не и употреба њему еквивалентне конструкције $\partial a+$ презент) у функцији допуне односно одредбе непрелазних глагола кретања и промене места у простору подлеже извесним ограничењима. У вези с рестрикцијама које се односе на глагол зависне структуре, Мелвингер (1986: 130) каже да зависни глагол „мора бити пунозначан; не смије, дакле, бити нити копула, нити модални, нити фазни, с тим да још мора означавати какву радњу или процес при чијем се вршењу ангажира воља агенса." У наставку наводимо неке од примера којима ауторка поткрепљује горе наведене тврдње: 
(5)

a) Овамо је дошла да коначно буде саслушана/*коначно бити саслушана. (Мелвингер 1986: 130)

б) Дошао је да почне радити/*почети радити. (Мелвингер 1986: 130)

Глаголи кретања и промене места у простору комбинују се и с перфективним и с имперфективним глаголима (6а) и 6б)). Међутим, у случају глагола кренути/кретати, вид зависног глагола постаје основ за разликовање глагола кретања кренути/кретати (= поћи/полазити) од фазног глагола кренути/ кретати (= почети/почињати) $)^{10}$. Као и сви остали фазни глаголи, и фазни глагол кренути/кретати употребљава се искључиво с допунским глаголом несвршеног вида (6в), док као глагол кретања кренути/кретати уобичајено добија допуну односно одредбу у виду глагола свршеног вида (уп. 6г) и 6д)).

(6)

a) Где ћеш?

- Идем бацити смеће/Идем да бацим смеће.

б) Где ћеш?

- Идем бацати риме/Идем да бацам риме.

в) Кренула сам бацати смеће још јутрос и завршићу тек вечерас/Кренула сам да бацам смеће још јутрос и завршићу тек вечерас.

г) Где ћеш?

- Ево, кренула сам бацити смеће/Ево, кренула сам да бацим смеће.

д) Где ћеш?

- ??Ево, кренула сам бацати смеће/Ево, кренула сам да бацам смеће.

Синтаксичко понашање српских глагола кретања и промене позиције у простору посебно је занимљиво због једне особености њихове употребе типичне за разговорни стил. Наиме, уколико се употребе у императиву, ови се глаголи, осим с инфинитивом односно с његовим финитним еквивалентом да + презент (7a), 7б), 7г), 7д), 7ж) и 7з)), веома често комбинују с још једним императивом (7в), 7ђ), 7е), 7и) и 7j) $)^{11}$.

${ }^{10}$ Како фазни глаголи спадају међу глаголе подизања, треба се сетити једне веома битне карактеристике глагола подизања. Они, наиме, немају сопственог субјекта, већ га деле с допунским глаголом. Уколико ни допунски глагол нема субјекта, неће бити „подигнутог” субјекта ни уз управни глагол подизања. То значи да фазни глагол кренути/кретати (= почети/почињати) може добити допуну и у виду бесубјекатског глагола (Креће севати/Kреће да сева), док се у функцији допуне односно одредбе глагола контроле кренути/кретати (= поћи/полазити) не могу јавити бесубјекатски глаголи. За више информација о глаголима подизања в. Московљевић Поповић (2008: 85-94).

${ }^{11}$ Осим у 2. лицу једнине, ова се конструкција јавља и у 1 . и 2. лицу множине императива (Изађи помози људима; Изађите помозите људима; Изађимо помозимо људима). 
(7)

a) Мама, иди купити књиге.

б) Мама, иди да купиш књиге.

в) Мама, иди купи књиге.

г) Мама, иди их купити.

д) Мама, иди да их купиш.

ђ) Мама, иди купи их.

е) Мама, иди их купи.

ж) Петре, иди се играти!

3) Петре, иди да се играш!

и) Петре, иди играј се!

j) Петре, иди се играј!

Ову појаву, нерегистровану и необјашњену у постојећој литератури, назвали смо редупликаиијом императива ${ }^{12}$. Својствена је, чини се, првенствено најучесталијим глаголима кретања и промене позиције у простору ( $u \hbar u, o m u \hbar u$, доћи, поћи, ући, изаћи, сести, лећи итд. $)^{13}$.

Оваква употреба императива типична је за неформалну усмену комуникацију, те се ређе бележи у писаној форми. У сваком случају, пренос ове конструкције у писани облик представља немали правописно-синтаксички проблем. Будући да би се могло рећи да у примерима 7в), 7ђ) и 7и) други императив у низу алтернира с инфинитивом односно конструкцијом $\partial a+$ презент, намеће се питање употребе зареза између двеју императивних форми. Уколико у поменутим примерима сваки други императив у низу третирамо као независну конструкцију, први и други императив одвојићемо зарезом (уп. Иди, купи књиге са Иди и купи књиге и Иди, па купи књиге). Ако пак сматрамо да други императив у низу треба да добије статус „императивне финалне допуне односно одредбе” јер представља алтернативу инфинитиву односно њему еквивалентној финитној конструкцији $\partial a+$ презент у функцији допуне (Иди купи књиге) односно одредбе (Иди у књижару купи књиге) непрелазних глагола кретања, у примерима 7в), 7ђ) и 7и) нећемо употребити зарез. Потребно је, дакле, у потпуности објаснити овакву употребу императива и одредити синтаксички статус другог императива у низу.

Познато је да у конструкцијама састављеним од управних глагола и њихових инфинитивних допуна уобичајено долази до пењања клитика, тј. до њиховог померања из инфинитивне у надређену финитну клаузу (7г) и 7ж)). Клитике пак остају унутар инфинитиву еквивалентне конструкције $\partial a+$ пре-

\footnotetext{
${ }^{12}$ В. Поповић Пизари (2018: 62).

${ }^{13}$ Редупликација императива карактерише и поједине глаголе субјекатске контроле с граматичким субјектом који не спадају међу непрелазне глаголе кретања и промене места у простору (Изволи попиј нешто; Узми једи).
} 
зент $^{14}$, и то на позицији непосредно иза комплементизатора да (7д) и 7з)). У конструкцијама које се састоје од императива глагола кретања и императива другог глагола, клитике се смештају или непосредно иза другог императива (7ち) и 7и)) или се пењу (7e) и 7j)).

Осим инфинитива односно њему еквивалентне финитне конструкције $\partial a+$ презент с кореферентним субјектом, у функцији допуне односно одредбе непрелазних глагола кретања и промене места у простору могуће је употребити и конструкцију $\partial a+$ презент с некореферентним субјектом, тј. са субјектом који није идентичан субјекту управне структуре. Услов који мора бити задовољен да би се оваква конструкција могла реализовати јесте постојање кореферентности између индиректног прономиналног објекта ${ }^{15}$ зависне и граматичког субјекта управне структуре (8а). Московљевић Поповић (2015: 195) сматра да би конструкције попут 8a), ,требало анализирати као реченице у којима се успоставља један посебан, у досадашњој лингвистичкој теорији недовољно уочен и разјашњен облик облигаторне контроле”.

У вези с примером (8а), треба нагласити да је финална конструкција $\partial a+$ презент употребљена у функцији допуне управног глагола кретања, због чега није комутабилна с одредбеном финалном конструкцијом $\partial a+$ потенцијал (уп. 8а) и 8б)). Уколико пак надређени глагол кретања већ има имплицитну или експлицитну допуну са значењем циља кретања (8в) и 8д)), у том случају финална конструкција $\partial a+$ презент с некореферентним субјектом има статус одредбе глагола кретања и комутабилна је с одредбеном финалном конструкцијом $\partial a+$ потенцијал (уп. 8в) и 8г), као и 8д) и 8ђ)). Скрећемо при томе пажњу на чињеницу да се у примерима 8в) и 8 д), који садрже одредбену финалну конструкцију $\partial a+$ презент, успоставља исти тип облигаторне контроле као у примеру 8а), који садржи допунску финалну конструкцију $\partial a+$ презент. У примеру 8ж), који садржи одредбену финалну конструкцију $\partial a+$ презент с некореферентним субјектом, комутабилну с конструкцијом $\partial a+$ потенцијал (уп. 8ж) и 83)), изостаје пак било какав облик облигаторне контроле.

(8)

a) Где идеш? - Идем да ми Мара објасни хемију.

б) Где идеш? - *Идем да би ми Мара објаснила хемију.

в) Зашто идеш на час? - Идем (на час) да ми Мара објасни хемију.

г) Зашто идеш на час? - Идем (на час) да би ми Мара објаснила хемију.

${ }^{14} \mathrm{O}$ изостанку пењања клитика из инфинитивне у надређену финитну клаузу, као и о антиципативном распоређивању клитика из зависне конструкције $\partial a+$ презент в. Поповић (1997: $345 ; 347-348)$.

${ }^{15}$ Овај индиректни објекат носилац је семантичке улоге реципијента или бенефицијента (Московљевић Поповић 2008: 101). 
д) Где идеш? - Идем код Маре да ми објасни хемију.

ђ) Где идеш? - Идем код Маре да би ми објаснила хемију.

е) Зашто је отишао у село? - Отишао је (у село) да се мало одмори.

ж) Зашто је отишао у село? - Отишао је (у село) да се Мара мало одмори.

3) Зашто је отишао у село? - Отишао је (у село) да би се Мара мало одморила.

Из досад наведених примера види се да се у конструкцијама које се састоје од управног глагола кретања и инфинитива односно његовог финитног еквивалента $\partial a+$ презент јављају следеће врсте контроле: 1) облигаторна контрола која се темељи на кореферентности неисказаног субјекта зависне и граматичког субјекта управне структуре, а карактерише је употреба инфинитива односно конструкције $\partial a+$ презент (с кореферентним субјектом) у функцији допуне односно одредбе управног глагола (4а)-4д); 6а), 6б) и 6г); 7а), 7б), 7г), 7д), 7ж) и 7з)), 2) облигаторна контрола која подразумева кореферентност индиректног прономиналног објекта зависне и граматичког субјекта управне структуре и употребу допунске односно одредбене финалне конструкције $\partial a$ + презент с некореферентним субјектом (8a), 8в) и 8д)) и 3) опциона контрола која се везује искључиво за одредбене финалне конструкције $\partial a+$ презент с кореферентним односно некореферентним субјектом (уп. 8е) и 8ж)).

Овим трима типовима контроле додали бисмо још један - заједничку (подељену) контролу која карактерише реченице попут 9а) и 9в). У примеру 9а) финална конструкција $\partial a+$ презент с некореферентним субјектом има статус допуне (уп. 9а) и 9б)), док иста конструкција у примеру 9в) има статус одредбе, због чега је комутабилна с одредбеном финалном конструкцијом $\partial a+$ потенцијал (уп. 9в) и 9г)). У примерима 9а) и 9в), субјекат и предикат зависне конструкције употребљени су у плуралу, а денотат субјекта управне садржан је у денотату субјекта зависне структуре.

(9)

a) Где идеш?

- Идем да се Мара и ја договоримо о заједничким активностима.

б) Где идеш?

- *Идем да бисмо се Мара и ја договориле о заједничким активностима.

в) Где идеш?

- Идем код Маре да се договоримо о заједничким активностима.

г) Где идеш?

- Идем код Маре да бисмо се договориле о заједничким активностима. 


\section{4. ЗАКЉУЧАК}

На крају овога рада, износимо неколико закључних напомена у вези с употребом непрелазних глагола кретања и промене позиције у простору у српском језику. Ови се глаголи убрајају међу глаголе субјекатске контроле и могу се комбиновати како с финалним клаузалним допунама и одредбама у виду инфинитива или инфинитиву еквивалентне финитне конструкције $\partial a+$ презент (с кореферентним субјектом), тако и с финалним клаузалним допунама и одредбама у облику финитне конструкције $\partial a+$ презент с некореферентним субјектом. Финалне инфинитивне конструкције карактерише искључиво облигаторна контрола, док се унутар финалних финитних конструкција $\partial а$ + презент може успоставити било који тип контроле (облигаторна, опциона или заједничка).

У раду смо скренули пажњу и на чињеницу да се у разговорном стилу често срећу конструкције састављене од императива непрелазних глагола кретања и још једног императива. Ову појаву назвали смо редупликацијом императива и с њом у вези истакли неопходност да се јасно одреди синтаксички статус другог императива у низу. Питање је, наиме, хоћемо ли овакав императив третирати као независну конструкцију или ћемо му доделити статус „императивне финалне допуне односно одредбе” непрелазних глагола кретања и промене позиције у простору.

\section{ЛИТЕРАТУРА}

Белић 2005: Bojan Belić, Complement verb variation in present-day Serbian (doctoral dissertation), The Ohio State University, Columbus.

Зец 1987: Draga Zec, On Obligatory Control in Clausal Complements, in: M. Iida, S. Wechsler \& D. Zec (yp.), Working Papers in Grammatical Theory and Discourse Structure (139-168), CSLI, Stanford, CA.

Мелвингер 1986: Јасна Мелвингер, Инфинитивна кондензација финалне зависне клаузе у сувременом хрватском или српском, НССУВД, 15/1, 123-131.

Мишкељин 2012: Ivana Miškeljin, Infinitival complements in Serbian - A Generative Approach, Filolog V, 199-209.

Московљевић Поповић 2008: Jasmina Moskovljević Popović, Ogledi o glagolskoj potkategorizaciji, Beograd: Čigoja štampa. 
Московљевић Поповић 2015: Јасмина Московљевић Поповић, Односи кореферентности у сложеној реченици са допунском клаузом, Јужнословенски филолог, LXXI/3-4, 187-202.

Поповић 1997: Љубомир Поповић, Ред речи у реченици, Београд: Друштво за српски језик и књижевност Србије.

Поповић Пизари 2018: Milena Popović Pisarri, Glagoli s dopunom u infinitivu u italijanskom i srpskom jeziku (doktorska disertacija), Filološki fakultet, Beograd.

Прањковић 2013: Ivo Pranjković, Gramatička značenja, Zagreb: Matica hrvatska.

Проговац 1993: Ljiljana Progovac, Locality and subjunctive-like complements in Serbo-Croatian, Journal of Slavic Linguistics 1, 116-144.

Проговац 2005: Ljiljana Progovac, A Syntax of Serbian - Clausal Architecture, Slavica, Bloomington.

Тодоровић 2012: Natasa Todorovic, The Indicative and Subjunctive da-complements in Serbian - A Syntactic-Semantic Approach (doctoral dissertation), Chicago: University of Illinois.

\section{VERBS OF MOTION AND CHANGE OF POSITION AS SUBJECT-CONTROL VERBS IN SERBIAN}

\section{Summary}

In this paper we analyze constructions that consist of an intransitive motion or position-change verb and an infinitive or its finite equivalent (complementizer $d a$ 'that' + present tense) as a complement or an adjunct of the matrix verb. We emphasize the fact that in spontaneous spoken Serbian the imperative of intransitive motion and position-change verbs combines not only with an infinitive or its finite equivalent, but also with another imperative form (Иди спавати (Idi spavati)/Иди да спаваш (Idi da spavaš)/Иди спавај (Idi spavaj)). We also give an overview of all the different types of $d a+$ present constructions (both with coreferential and non-coreferential subjects) that can be used as complements or adjuncts of intransitive motion and position-change matrix verbs and we define the type of control (obligatory, non-obligatory, and shared control).

Keywords: verbs of motion, subject control, infinitive, $d a+$ present, imperative. 